\title{
Pulling Apollo Apart
}

\author{
Richard Hunter \\ University of Cambridge, Faculty of Classics, Trinity College \\ rlhı@cam.ac.uk
}

\author{
Rebecca Laemmle \\ University of Cambridge, Faculty of Classics, Pembroke College \\ rl545@cam.ac.uk
}

Received December 2018 | Accepted April 2019

\begin{abstract}
This paper considers the etymologising of the names of Apollo in Plato, Cratylus and Plutarch, The E at Delphi. It is argued that the richness of the god's etymologies in these texts and in classical literature more generally suggests that a special connection was seen between the nature of Apollo and the practices of etymologising; this connection is in part owed to the similarities between etymologising and prophetic speech and practice and in part to the fact that ancient etymology reveals settled, unchanging truths about language, just as Apollo manifests the settled, unchanging order of the world. The paper sheds light not just upon ancient etymological practice from Homer onwards but also on certain conceptions of the nature of Apollo.
\end{abstract}

\section{Keywords}

Apollo - etymology - Dionysus - Homer - Pan - Plato - Plutarch

\section{Introduction}

Despite much scholarly effort there is no modern consensus on the etymology of either 'A $\pi \dot{\partial} \lambda \lambda \omega \nu$ or $\Phi \circ \hat{\imath} \beta \circ \varsigma^{1}{ }^{1}$ and in antiquity too no member of the Olympian

1 The dictionaries of Frisk, Chantraine and Beekes all class the etymologies of both 'A $\pi \dot{0} \lambda \lambda \omega \nu$ and Фoîßos as 'unerklärt', 'inconnue' etc. Burkert 1975 was a very influential intervention in

(C) RICHARD HUNTER AND REBECCA LAEMMLE, 2019 | DOI:10.1163/1568525X-12342684

This is an open access article distributed under the terms of the $8 \mathrm{Gn}_{\mathrm{B}} \mathrm{A}_{\mathrm{d}} \mathrm{e}$ License. 
pantheon seems to have offered so fertile a stimulus to the very different ancient practices of etymologising. Texts from all periods of classical antiquity bear eloquent witness to how the god's two principal names fed the etymologising impulse. In this paper we consider two particularly important moments of ancient etymologising about the god. The first is Socrates' account of the god's name in Plato's Cratylus, to which all subsequent ancient discussions of the matter are indebted; this text both has a special, foundational importance for the subject and also looks back to, and subsumes within itself, the rich tradition of etymological play in pre-Platonic poetry. The second text with which we shall be concerned is part of Plutarch's essay The E at Delphi, a later (Platonising) text which, like the Cratylus, gives full rein to the breadth of Apollo's spheres of activity, while also emphasising the essential and unchanging nature of the god. Our concern is what these texts can tell us, not just about the practice of ancient etymologising, but about how Apollo himself was imagined, what, in other words, both he and his name 'meant.' As the choice of the Plutarchan text suggests, moreover, an important focus will be on $\mu \alpha \nu \tau i x \eta^{\prime}$, the Apolline art which will prove both close to and illustrative of the practices of ancient etymologising; if Apollo is not quite the 'god of etymology' as he is the 'god of prophecy', the analogy will prove not untrue to his significance for the ancient investigation of the meaning of words.

In the course of this paper we shall often have occasion to refer to 'explicit' etymology. By this we mean, as is in fact common usage, not merely the explanations of words found in the etymological lexica which survive from late antiquity and the Byzantine period, but also passages of classical texts in which an etymology is clearly marked or pointed out, standardly through one of a fa-

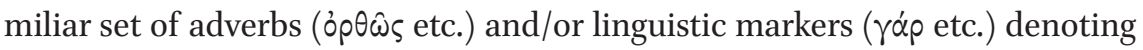
causality. ${ }^{3}$ Although the nature of our evidence, with prose only coming into the picture in the fifth century, imposes caution, there is much which suggests a link between the growth of such 'explicit' etymologising and the linguistic and anthropological interests of some of the leading figures of the fifth-century sophistic movement. Such a link would fit nicely, for example, with the impression that, in what survives of Attic tragedy, 'explicit' etymologising is more

the debate about the etymology of 'A $\pi \dot{0} \lambda \lambda \omega \nu$, cf. Heubeck 1987; Nagy 2004. On the practice of etymology in antiquity cf. Sluiter 2015 and Most 2016, both with further bibliography. Sluiter 2015 is an important discussion of the etymologies of Apollo in the Cratylus, but her focus is different from ours.

2 We are very conscious that the present discussion is the tip of an iceberg-Stoic etymologising of the god's name, for example, would occupy a long paper by itself.

3 Cf., e.g., below on A. Ag. 1082. 
common in Euripides than in Aeschylus or Sophocles. ${ }^{4}$ In the wake of these fifth-century developments, Plato's Cratylus, or rather the way in which it was read in antiquity, played a crucial role in establishing something like an equation between 'explicit' etymology and etymology tout court, an equation which still exerts a hold over modern discussions of ancient practice; we shall return to this at the end. That classical texts from Homer onwards, however, are also full of 'implicit' etymologising or 'etymological play' of a richness that defies systematic cataloguing is too well known to require demonstration, and it will become clear that this is no less true of the Cratylus, in which Socrates' 'explicit' etymologies are only one part of the extraordinary linguistic texture of the dialogue. What is most important in fact-as scholarship has indeed increasingly recognised - is not to fetishise the difference between 'explicit' and 'implicit' etymologising (of all kinds) in the interpretation of ancient texts; to do so misrepresents something important about the ancient etymological project.

\section{Socrates' Apollo}

The account of Apollo's name in the Cratylus (404c5-406a4) ${ }^{5}$ competes with the discussion (403a5-405b4) of Hades, where all of us are destined to dwell longest, for the honour of being the longest of Socrates' discussions of individual divine names. Apollo, however, certainly wins in terms of the number of etymologies offered: whereas Socrates discusses only two etymologies for "Aıठฤ $\rceil$, an allegedly common one from $\dot{\alpha}-1 \delta$-, 'unseen', 'hidden from view', and the one

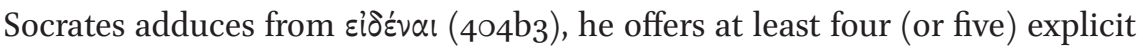

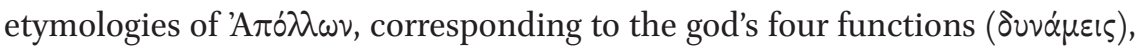
in a discussion marked by a striking ring composition (404e1 405e4):

\begin{tabular}{|c|c|}
\hline i $\alpha \tau \rho ı x \eta ́$ & $\dot{\alpha} \pi 0 \lambda \circ v^{\prime} \omega \nu$ and $\dot{\alpha} \pi 0 \lambda v^{\prime} \omega \nu$ \\
\hline$\mu \alpha \nu \tau i x \eta^{\prime}$ & $\dot{\alpha} \pi \lambda \circ \hat{v} \nu^{7}$ \\
\hline
\end{tabular}

4 For a particularly pointed 'Apolline' etymology in Euripides cf. Phaethon fr. 781.11-13 Kannicht (= 224-226 Diggle). On etymologising in Euripides more generally cf., e.g., Van Looy 1973; Segal 1982 .

5 Cf. Sluiter 2015, 896-922.

6 Cf. Sluiter 2015, 913 .

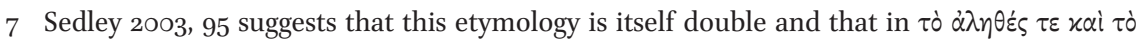
$\dot{\alpha} \pi \lambda \circ 0 \hat{\nu}$ at $405 \mathrm{c} 2$ the first syllable of $\dot{\alpha} \lambda \eta \theta \dot{\varepsilon} \varsigma$ is also involved in the etymology. We are sympathetic to this view, although it is not confirmed in the summary at 406a2 and it was the etymology from $\dot{\alpha} \pi \lambda \circ \hat{v} v$ which was to be remembered by the subsequent tradition. Sluiter 2015 , 914 adopts the traditional view. Cf. further below. 


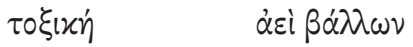

$$
\begin{aligned}
& \mu \circ v \sigma i x \eta \dot{~ o \mu o \pi o \lambda \omega \nu ~}
\end{aligned}
$$

Beyond these explicit etymologies, the introductory section of the discussion, where Apollo is first brought in alongside Pherrephatta, twice clearly points to, but avoids spelling out the ill-omen of, another well-established etymol-

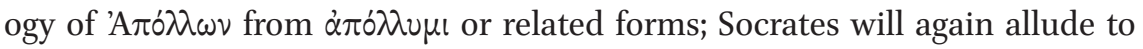
(and reject) this etymological connection at the conclusion of his discussion of the name of Apollo (405e4). The very same words which evoke this danger-

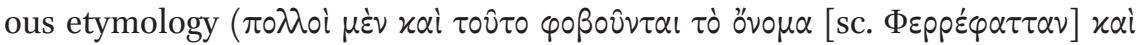

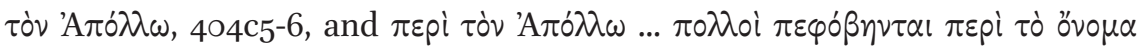
$\tau \circ \hat{v} \theta \varepsilon \circ \hat{v}, 404 \mathrm{~d} 8-\mathrm{e} 2)$ moreover hint at yet another, and again very common, etymological explanation of the god's name as $\alpha$ - $\pi 0 \lambda$ $\varsigma$, 'not many/much'.

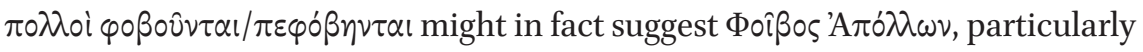

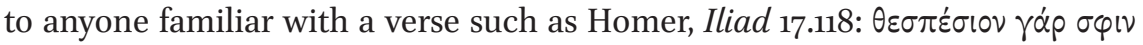

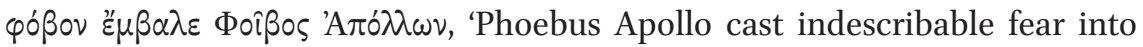
them'. How 'etymological' a hearer or reader do you have to be not to hear $\varphi$ ó

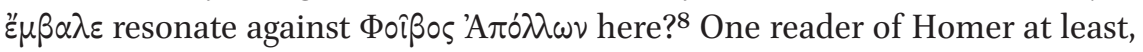
and one with a very sharp eye for etymology, namely Eustathius, recognised

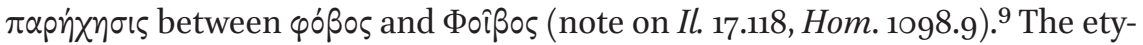
mology in the Cratylus of 'A $\pi \dot{o} \lambda \lambda \omega \nu$ as archer-god $(<\dot{\alpha} \varepsilon \dot{\beta} \beta \dot{\alpha} \lambda \lambda \omega \nu)$ suggests that the similarity between - $\pi \dot{o} \lambda \lambda \omega \nu$ and $\beta \alpha \dot{\alpha} \lambda \omega \nu$ was easy enough to feel in antiquity. ${ }^{10}$ We will return at the end to what such examples can teach us about etymological readings.

The discussion of 'Apollo' in the Cratylus, then, pullulates with etymologies. This god is, of course, far from unique in the multiplicity of his etymologies and indeed, as David Sedley put it, "the most highly vaunted etymologies [in the Cratylus] are ... those which identify two or more co-existent meanings in the same word". ${ }^{11}$ Nevertheless, it is important to note that no other name

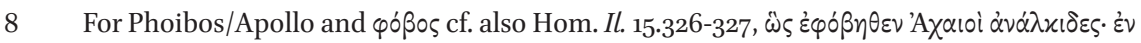

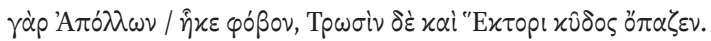

9 Rank 1951, 71-72 notes the sound-play between $\varphi$ óßం and $\Phi$ оißßo in this Homeric verse, but without reference to Eustathius or comment on $-\beta \alpha \lambda \varepsilon \sim-\pi \dot{0} \lambda \lambda \omega \nu$. For another such paronomastic play of $\varphi$ óßos and $\Phi$ oîßos cf. A. Pers. 205-206 (within an account of a bird-omen).

10 That $\Phi$ ○îßৎ is not apparently connected with $\varphi$ ó $\beta \circ \varsigma$ in what survives of explicit ancient etymologising is not a strong argument against the clear resonances in Plato's text. There have, in fact, been modern attempts to derive $\Phi$ oîßం from $\varphi$ óßం५, cf. Schmid 1923-1924; Kretschmer 1927, 199 .

11 Sedley 2003, 36; cf. also Sluiter 2015, 912 on the "simultaneously true" etymologies of Apollo's name in the Cratylus. The account of Socrates' discussion of Apollo's name in 
or word in the Cratylus is given the number of etymologies with which the name of Apollo is honoured. There may, however, seem to be a tension between the Platonic etymology of 'A $\pi \dot{\delta} \lambda \omega \nu$ in connection with $\mu \alpha \nu \tau i x \eta$ ' as 'single' $(\dot{\alpha} \pi \lambda \circ \hat{v} v)$ and the multiplicity of etymologies, but that tension will in fact reveal something important about the god and about the field of language in which both prophecy and etymology move.

In considering the etymologising of Apollo in the Cratylus, it is indeed the field of language with which we must begin. Whereas Socrates asserts that the name of mantic Apollo proclaims his truthfulness, it is above all Hermes and his son Pan, who are associated with the mutability and potential deceptiveness of language:

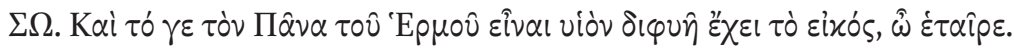

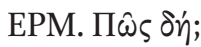

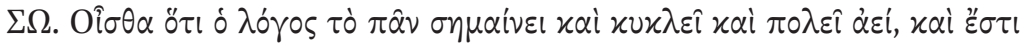

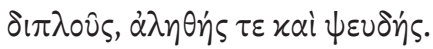

EPM. Пஷ́ $v v \gamma \varepsilon$.

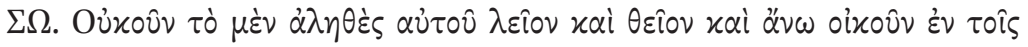

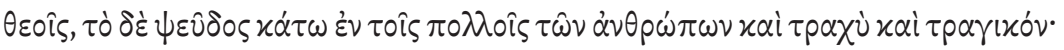

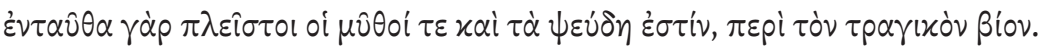

EPM. П'́ $v v \gamma \varepsilon$.

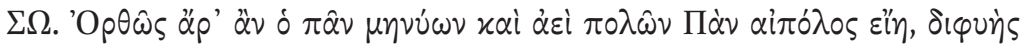

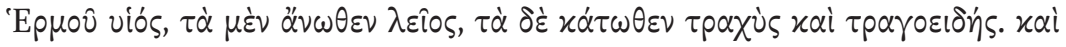

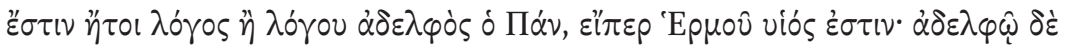

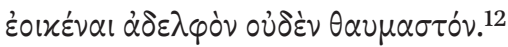

Soc. And it is indeed reasonable, my friend, that Pan is the doublenatured son of Hermes?

Herm. How so?

Soc. You know that logos signifies everything and circulates and is forever on the move and it is double, both true and false.

Herm. Yes indeed.

Trivigno 2012, 47-49 seems to suffer from a misunderstanding of the nature and purpose of ancient etymologising: he finds the etymologies "particularly implausible" and suggests that their very number shows that Apollo is "certainly not simple [emphasis original] but varied and complex". For Trivigno 2012, 54 it is "impossible" that "all of these etymologies are jointly correct" [emphasis original], and we are offered no way of "choosing amongst competing etymologies". 
Soc. So, the true part of it is smooth and divine and lives up there with the gods. The false part, however, lives down among the mass of men and is rough and tragikon; for here are the majority of myths and falsehoods, in the tragikos life.

Herm. Yes indeed.

Soc. So the one who bears witness to everything and is always on the move would correctly be 'Pan aipolos [goatherd]', the double-natured son of Hermes, in his upper parts smooth, but down below rough and in the form of a goat [tragoeides]. And Pan is either logos or the brother of logos, if he is the son of Hermes; it is nothing remarkable if brother should resemble brother.

Pan, it is claimed, is the son of Hermes ('he who created speech', 408b1), and as such he is either the brother of logos or logos itself. The statement that 'speech

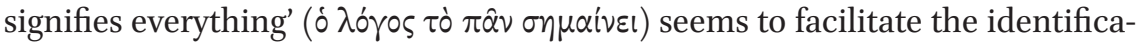
tion of logos with Pan, ${ }^{13}$ whose name also 'means everything', as is explicitly spelled out already in the (almost certainly 5 th century) Homeric Hymn to Pan:14

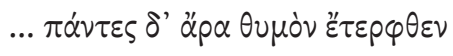

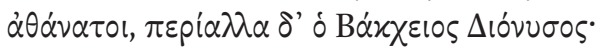

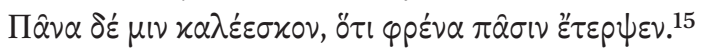

... and all the immortals were delighted in their hearts, and most of all Bacchic Dionysus; and they called him Pan, because he delighted the hearts of all.

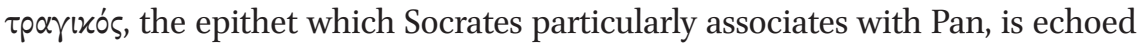
later in the text in connection with the history of language, when Socrates observes that the first words have been buried under later interventions, which he subsumes under the term $\tau p \alpha \gamma \omega \delta \delta \hat{\imath}$ :

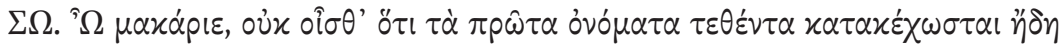

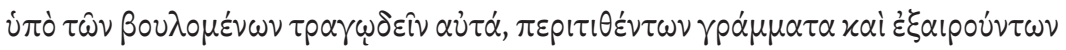

13 The identification is perhaps also punningly confirmed by Hermogenes' repeated $\pi \dot{\alpha} v v \gamma \varepsilon$, in response to claims about the near-identity of $\Pi \dot{\alpha} \nu$ and logos. It is tempting to see in this effect also an allusion to Pan's erotic connection to Echo, but that is not certainly attested before Hellenistic poetry.

14 On the Homeric Hymn to Pan see Thomas 2011 (with 169-172 on the date).

15 h.Pan. 45-47. 


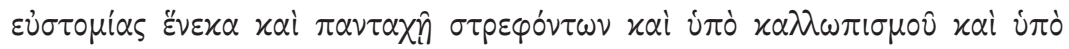
¿póvov. ${ }^{16}$

Soc. My friend, do you not know that the words which were first given have long since been covered over by those who wished to tragöidein them; they add and subtract letters for the sake of euphony and distort the words in every way both to prettify them and through the passage of time.

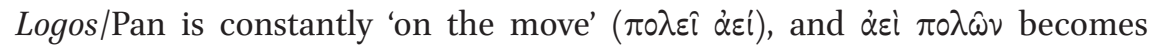
the explanation of the second part of his full name, Pan Aipolos. Both Pan's name and his epithets change before our eyes: Pan evolves into Pan Aipolos, and $\tau$ parixós shifts between 'goatlike' and 'tragic'. In this persistent mobility Pan really does embody logos: words ( $\lambda$ óros) change over time-not only Heracliteans might say that they are in constant flux — and their true meaning is distorted, often beyond recognition, whether deliberately or simply through the 'natural' lapse of time. ${ }^{17}$

In the Cratylus, Logos/Pan's $\delta เ \pi \lambda \circ \hat{v} v$ nature casts him in opposition to Apollo, whose prophecy is $\dot{\alpha} \pi \lambda \circ \hat{v} v$ (405c2), as also does his lower, $\tau$ parıxóv half, which

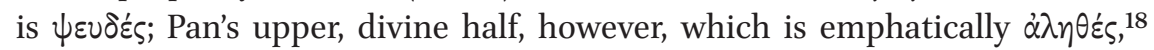
shows, on the other hand, a marked overlap with the mantic and truthful Apollo. This is reflected in the tantalising explanation of his epithet aimónos which combines two words which, in isolation, are also parts of Apollo's etymologies in the Cratylus ( $\dot{\alpha} \varepsilon$ from $\dot{\alpha} \varepsilon \dot{\beta} \beta \dot{\alpha} \lambda \omega \omega \nu, \pi 0 \lambda \omega \hat{\omega}$ from $\delta \mu 0-\pi 0 \lambda \hat{\omega} \nu) .{ }^{19}$ Here is a crucial way in which the mantic art and etymologising, as we see it in the Cratylus, overlap. Words change and/or may be used in shifting, ambiguous

16 Pl. Cra. 414c4-7.

17 It is noteworthy that three other etymologies in the Cratylus combine $\dot{\alpha} \varepsilon \dot{i}$ and $\dot{\rho} \varepsilon \hat{\imath}-\alpha \dot{\eta} \hat{\rho}$

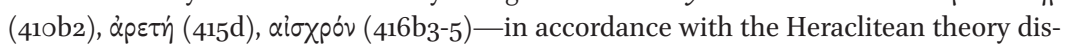
cussed in the dialogue.

18 Cf. further below. Callimachus too seems to play with an opposition, both real and etymological, between Apollo and Pan in the Hymn to Apollo (vv. 9 and 110).

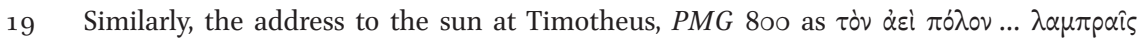

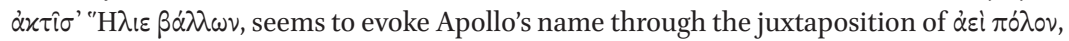
cf. Hunter 1986, 59. For the evidence for the identification of Apollo and the sun in classical texts cf. Pfeiffer on Call. fr. 302; Diggle 1970, 147. In the Cratylus, Socrates makes no explicit link between Apollo and Helios, in part apparently because he wishes to associate the principal heavenly bodies with flux and cosmic change (cf. Sedley 2003, 105-106), which are so notably absent from the Apolline etymologies. One of Socrates' etymolo-

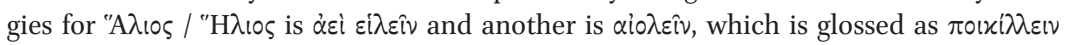
(409a1-5). 
ways, but it is etymology which, it is claimed, reveals the settled truths that lie behind language, truths impervious to the changes and distortions of time, just as the mantic art understands the past and the present and the future, even if the language in which it is expressed may be ambiguous and hard to comprehend. The apparent paradox which the Platonic Socrates parades is thus intended to provoke thought about the nature of the god. Apollo has no share in falsehood or constant movement and shifting; rather, as we shall see at greater length in Plutarch, the god is very often associated with an established and eternal ( $\dot{\alpha} \varepsilon \dot{i})$ order, and one which resists both the multiplicity and the change which characterise Pan. Etymology, at least as it is on show in the Cratylus and the subsequent tradition which was so heavily indebted to Plato, explains settled verities which may be hidden behind the distortions which language undergoes: so too, Apollo himself is always healer, prophet, archer and musician. ${ }^{20}$

The association of Apollo with truth was long established; Pindar had declared of the god's all-knowing mind:

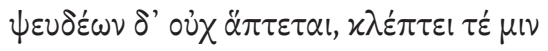

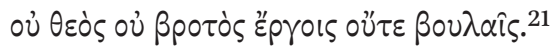

[Apollo's mind] has nothing to do with falsehoods, and no god or immortal deceives him in actions or words.

Elsewhere, the Platonic Socrates too insists, though in more than one tone of commitment or irony, on the god's unswerving truthfulness (cf., e.g., Pl. Ap. 21b6-7, R. 2.383a8-c5 on A. fr. 35 o Radt). Socrates' nonchalant equation in

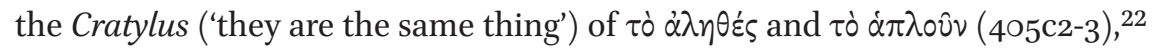
bound together by $\tau \varepsilon$ xai to confirm the equation linguistically, is also knowingly disingenuous. Nevertheless, whatever Socrates' tone here, Plato may already be 'pythagorising', as he is clearly about to do with his discussion of $\mu \circ v \sigma\left(x \eta^{\prime}:{ }^{23}\right.$ at least subsequently, but presumably earlier as well, Apollo was

20 These certainties are reflected, for example, in the pronouncements of the newborn god in the Homeric Hymn to Apollo (vv. 131-132) and in the in utero prophecy of the Callimachean god at Hymn to Delos (vv. 162-195).

21 Pi. P. 3.29-30. Pindar is here so emphatic in part because he is implicitly rejecting the Hesiodic story of how a raven informed Apollo of Coronis' betrayal: the scholia amusingly

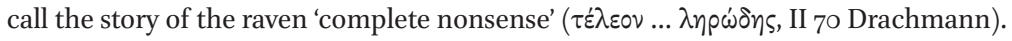

22 Cf. Sluiter 2015, 914.

23 Cf. Burkert 1962, 75-76. 
associated by Pythagoreans with the number One (e.g. Plu. Isis and Osiris 381 , cf. 393c), and despite Plato's appeal to the Thessalian term "A $\pi \lambda$ ouv for the god (Cra. 405C4), the etymology from $\dot{\alpha} \pi \lambda$ ov v very likely implicitly reflects the $\dot{\alpha}+\pi \circ \lambda \lambda$-etymology to which the beginning of the passage has already alluded. Given the importance of Apollo for Pythagoras, who himself bore a markedly Apolline name and who at least later was believed to have been interested in name-giving and perhaps also etymology, ${ }^{24}$ there was no god for whom such 'pythagorising' etymology was more appropriate. $\mu \alpha \nu \tau i x \eta$ and oracular utterance are indeed associated with Socrates' etymological operations in the dialogue itself ( $\mathrm{Cra}$. 396d-e, 411b4, 428c6-7), ${ }^{25}$ and at the beginning even Cratylus' attempts at etymologising are referred to as $\mu \alpha v \tau \varepsilon i \alpha$ (384a5). Although these passages have given rise to much discussion of Plato's potential debt to the religious 'expert' Euthyphro, they are usually passed over as playful jests, which of course they in part are. The undeniable playfulness, however, should not stop us from asking what might lie behind the teasing. The presentation of, and attitudes to, $\mu \alpha v \tau i x \eta$ and divination in the Platonic corpus are in fact very diverse, ${ }^{26}$ but their association with etymology seems to have been no passing whim.

$\mu \alpha \nu \tau i x \eta$ itself has a familiar place in the history of Greek etymology. In Euripides' Bacchae, Teiresias, an Apolline $\mu \alpha \dot{\alpha} v \tau \varsigma$, but here speaking on behalf (and perhaps under the power) of Dionysus, associates the term with $\mu \alpha v i \alpha$, an association which modern etymology confirms:

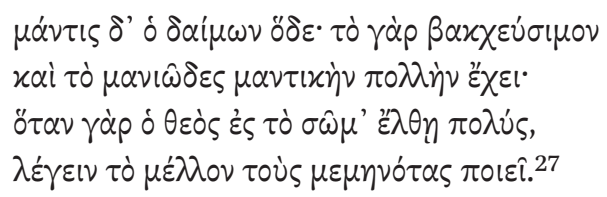

This god is also a seer (mantis), for the bacchic and the manic contain prophetic powers (mantike) in large measure. Whenever the god enters with force into someone's body, he causes those who have been maddened to tell the future.

In a famous passage of Socrates' 'palinode' in the Phaedrus, Socrates makes much of the link between $\mu \alpha v^{\prime} \alpha$ and $\mu \alpha v \tau i x \eta^{\prime}$, as he sets out the benefits which,

\footnotetext{
24 Cf. Cic. Tusc. 1.62, Ael. VH 4.17; further bibliography in Flinterman 2014, 346-347.

25 Cf., e.g., Morgan 2010, 69; Struck 2016, 48-49.

26 Cf., e.g., Morgan 2010; Struck 2016, ch. 1.

27 E. $B$ a. $298-3$ o1.
} 
through divine gift, $\mu \alpha v i \alpha$ has brought to mankind, for $\mu \alpha v$ i $\alpha$ is not an evil 'pure and simple' ( $\dot{\alpha} \pi \lambda \circ \hat{v} v, 244 \mathrm{a} 5-6)$ :

But it is worthwhile to adduce the point that among the ancients too those who gave things their names did not regard madness ( $\left.\mu \alpha v^{\prime} \alpha\right)$ as shameful or a matter for reproach; otherwise they would not have con-

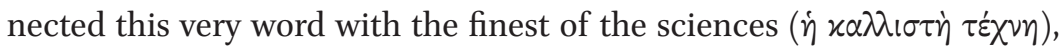
that by which the future is judged, and named it 'manic' ( $\mu \alpha v i x \eta \dot{)}$. No, they gave it this very name thinking madness a fine thing, when it comes by divine dispensation: whereas people now crudely throw in the extra $t$ and call it 'mantic' ( $\mu \alpha v \tau i x \eta$ '). So too when the ancients gave a name to the investigation which saner men make of the future by means of birds

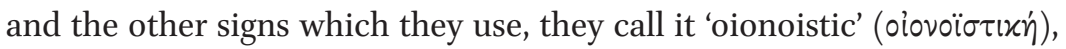
because its proponents in a rational way provide insight and information for human thinking; while the modern generation now call it 'oionistic'

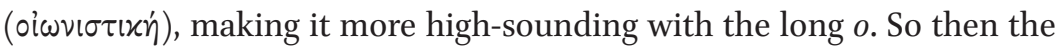
ancients testify to the fact that god-sent madness $\left(\mu \alpha v^{\prime} \alpha\right)$ is a finer thing than man-made sanity ( $\left.\sigma \omega \varphi p \circ \sigma v^{\prime} \eta\right)$, by the degree that mantic ( $\left.\mu \alpha \nu \tau i x \eta^{\prime}\right)$ is a more perfect and more valuable thing than oiōnistic (oi $\omega v i \sigma \tau i x \eta ́)$, both when name is measured against name, and when effect is measured against effect. ${ }^{28}$

Opinions will differ as to how seriously we are to take all this, ${ }^{29}$ and Socrates himself is subsequently to pour some cold water on it (Phdr. 264e-266b), but

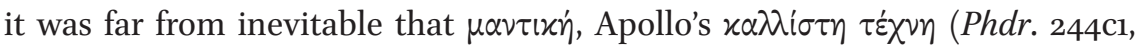
cf. 265 b3), should be explained through etymology and in connection with the ancient 'name-givers'. By resorting to etymology, did Socrates here choose a particularly appropriate mode of explanation, one which is-it should be noted-not used when he explains the other forms of beneficent madness (244d5-245a8)? Did Plato feel (not, perhaps, without a certain wry scorn) a special link between $\mu \alpha v \tau i x \eta$ (and hence Apollo) and etymology, two 'arts' which claim to reveal truths about the world which are otherwise hidden from men? Like $\mu \alpha \nu \tau i x$ ', etymology looks to the past (the name-givers) and to the present (in which the-often debated-significance of the names remains). As for the Apolline art par excellence, despite the fact that this passage of the Phaedrus

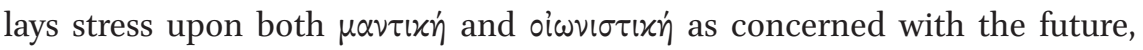
in reality both were, like etymology, just as much directed both to the past

28 Pl. Phdr. 244b6-d5 (trans. C. Rowe).

29 Cf., e.g., Sedley 2003, 33-34. 
(i.e. establishing the causes of something in the present) and the present itself; ${ }^{30}$ the role of Calchas, who knows 'the present, the future and the past' (Hom. Il. 1.70) is, as Plutarch was to make explicit (The E at Delphi 387b), a paradigmatic demonstration of this.

It is perhaps too rarely asked why in the Phaedrus Socrates gives this elaborate etymological epideixis. The explanation that it is a kind of extended footnote acknowledging that not all practices which are labelled $\mu \alpha \nu \tau i x \dot{n}$

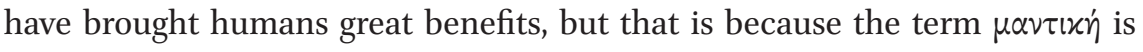
misapplied, seems true but too banal to explain the manner in which Socrates labours the point. Rather, we suggest that both kinds of prophetic art, divine $\mu \alpha \nu \tau i x \dot{\eta}$ and human oi $\omega \nu 1 \sigma \tau i x \dot{\eta}$, are etymologised here in part because of an important link, which is likely to have been felt well beyond discussion in the Academy, between etymologising and the mantic art, one which, as we have seen, is put on open display in the Cratylus. In etymologising the mantic art, then, as Socrates does in the Phaedrus, one is in fact (almost) practising it, and we will see presently a very similar example in Aeschylus' Agamemnon. It is tempting to go a little further and suggest that the two etymologies themselves illustrate the two forms of mantic practice which Socrates claims. If the derivation of $\mu \alpha \nu \tau i x \eta$ from $\mu \alpha v i x \eta$ was, as seems very likely, familiar both in Plato's day and already at the period in which the Phaedrus is set and was (paradoxically)

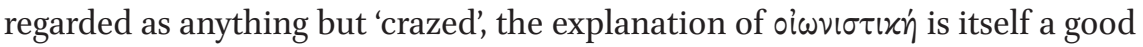

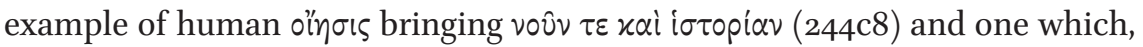
quite literally, comes about $\delta \imath^{\prime}$ opvi $\theta \omega v$ : Socrates looks at the birds, or (strictly

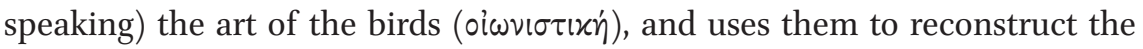
motivations of the name-givers of the past.

Both etymology and $\mu \alpha \nu \tau i x \eta$, when practised by experts, claim to allow us to understand the truth of things; as such, both practices might seem (though presumably not to Plato) also to resemble philosophy. Some later etymologists in fact rejected the link between $\mu \alpha \nu \tau i x \eta$ and $\mu \alpha v^{\prime} \alpha$ in favour of a connection between $\mu \alpha v \tau i x \eta$ and $\mu \hat{\omega}$ or $\mu \hat{\omega} \mu \alpha$, which was supposed to be synonymous with $\zeta \eta \tau \varepsilon \hat{\nu}$ (cf. EM 574.69-75); presumably the passage of the Cratylus which immediately follows the discussion of Apollo was crucial here: ${ }^{31}$

30 The distinction which Socrates makes between the 'crazed' but divinely inspired $\mu \alpha v \tau i x \eta$ of, say, the Pythia and human oi $\omega v i \sigma \tau i x \eta$ is important in the context of Plato and the Phaedrus, but may be less so in assessing the cultural valuation of $\mu \alpha v \tau i \eta^{\prime}$ more generally; it sharpens for rhetorical purposes what was anything but a clear-cut distinction in the Greek practice and discourse of divination. For further discussion cf. Dillery 2005; Flower 2008, 84-9o; Morgan 2010, 68.

Pl. Phdr. 244c-d is likely also to have contributed to these late definitions. 


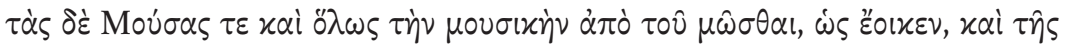

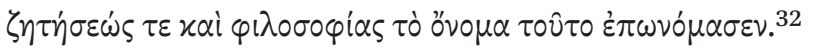

The Muses and music in general are, as it would seem, given this name from mōsthai and from searching and philosophy. ${ }^{33}$

We do not have to believe the Platonic Alcibiades that there is such a thing

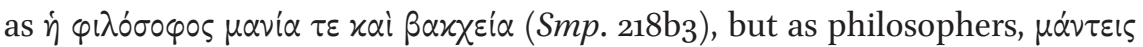
and etymologists are all 'searching', it is easy enough to see how associations between them might arise and be exploited. For Plutarch, much later, the matter was clear:

That the god is no less a philosopher than a prophet Ammonius seemed to all to postulate and prove correctly, with reference to this or to that one of his several titles; that he is Pythios for those that are beginning to learn and inquire ( $\delta(\alpha \pi v v \theta \alpha v \varepsilon \sigma \theta \alpha \mathrm{l})$; Delios and Phanaios for those to whom some part of the truth is becoming clear $(\delta \eta \lambda \circ v \tau \alpha l)$ and is being

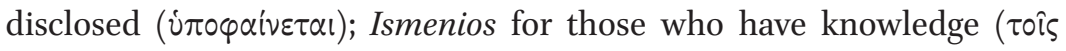

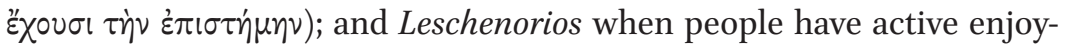
ment of conversation ( $\delta 1 \alpha \lambda \dot{\varepsilon} \gamma \varepsilon \sigma \theta \alpha l)$ and philosophic intercourse with

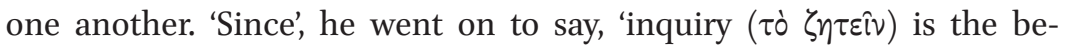

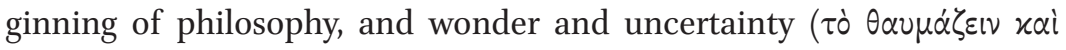
$\dot{\alpha} \pi$ opeiv) the beginning of inquiry, it seems only natural that the greater part of what concerns the god should be concealed in riddles, and should call for some account of the wherefore and an explanation of its cause ..... ${ }^{34}$

Apollo himself uses etymology to reveal truths about himself and to encourage us towards intellectual investigation. Apollo is, then, exactly the god in and on whose name one would expect etymology to flourish.

It is this very close connection between Apollo and the decoding of meaning in language which gives a particularly bitter twist to one of the most famous (and earliest) etymologising passages of Greek tragedy, namely Cassandra's denunciation of Apollo in Aeschylus' Agamemnon:

32 Pl. Cra. 406a2-5.

33 The unstated subject of the active ह่ $\pi \omega \nu$ ó $\mu \alpha \sigma \varepsilon v$ is, as standardly in the Cratylus, "the name-giver'.

Plu. The E at Delphi 385 b-c (trans. F.C. Babbitt, adapted). 


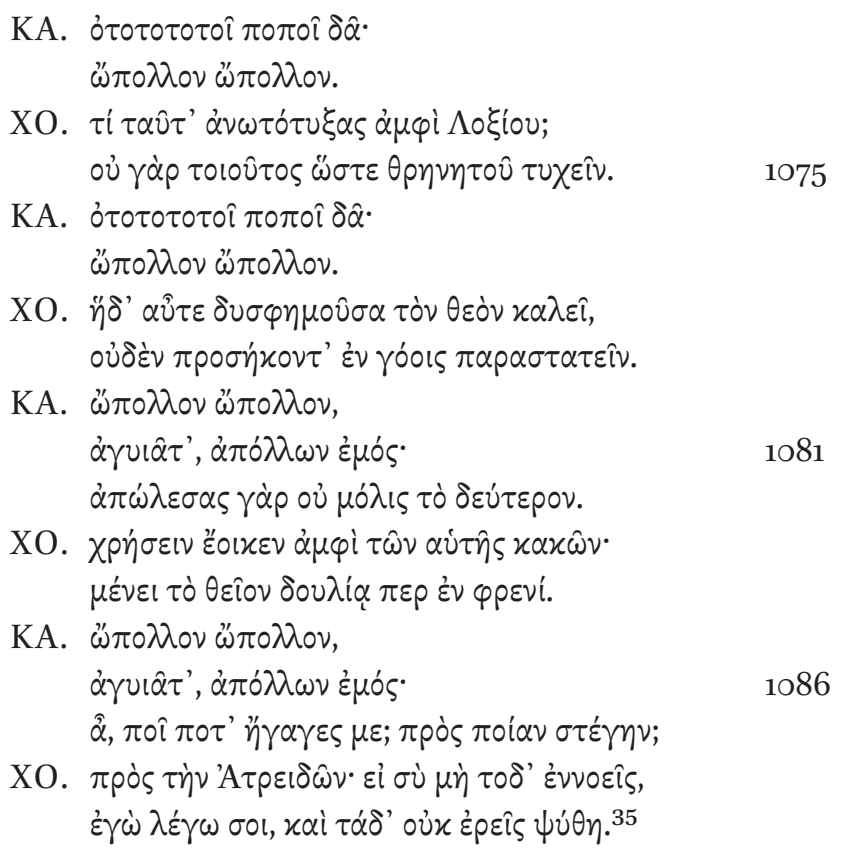

Cass. Ototototoi popoi daa! O Apollo o Apollo! Ch. Why have you raised this cry about Loxias? He is not such as to have anything to do with a mourner. Cass. Ototototoi popoi daa! O Apollo o Apollo! Ch. Look, again she calls on the god in an ill-omened way; it is not appropriate for him to be present at lamentation. Cass. Apollo, Apollo, God of the street, my destroyer (apollōn), for you have easily destroyed (apōlesas) me for a second time. Ch. She seems about to prophesy concerning her own misfortunes; divine gifts remain even in the mind of a slave. Cass. Apollo, Apollo, God of the street, my destroyer (apollōn). Ah, where on earth have you brought me? To what kind of dwelling? Ch. To the house of the Atreidai. If you do not realise this, I am informing you, and you will not say this was untrue.

The divinely inspired Cassandra here moves from inarticulate speech, the

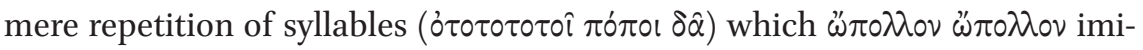
tates (or to which it is assimilated), to a full meaning which emerges in explicit

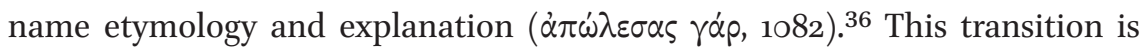

\footnotetext{
35 A. Ag. 1072-1089 (text of D.L. Page).

36 ráp is a very common etymological pointer, cf. Sluiter 2015, 914, discussing this same passage of the Agamemnon.
} 
mirrored by the chorus, who move from a quandary expressed though the verb $\grave{\alpha} \nu \omega \tau \tau^{\prime} \tau \nu \xi \alpha \varsigma$ in v. 1074, which again echoes and intensifies the inarticulate cry, to

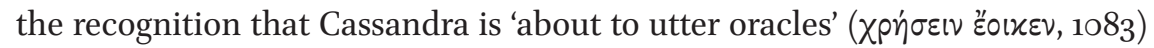
under Apollo's influence. As an Apolline $\mu \alpha \dot{\alpha} v \tau \iota \zeta$, Cassandra is merely 'doing

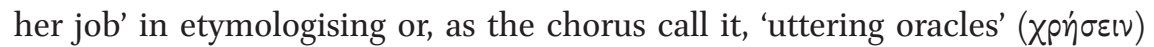
here. More importantly, the shift from a sequence of inarticulate syllables to meaningful language revealed in etymology tracks the role of Apollo in establishing a fixed order for both the past and the present which is uncovered through etymology.

Etymology, then, reveals the order, not just in the world but also in language (as a reflection of that world); it is itself a sign that language is both meaningful and settled. In many ancient ways of imagining cosmic history, it was not always so. Just as, in the Hesiodic account, the Olympian order replaced a violent disorder which proceeded, so too meaningful, settled language was never just a given. If we ask what, in the ancient imagination, came before Apollo and the name-givers whose work etymology seeks to recover, then various answers are possible, but one mytho-poetic answer was dramatised in the Hesiodic Typhoeus, a monster who, as is well recognised, ${ }^{37}$ represents (inter alia) an inarticulate and disordered instability of sound and language (Th. 820-868). In the Homeric Hymn to Apollo Typhaon is the child of Hera who entrusts him for rearing to the Delphic serpent who is to be slain by Apollo (305355, cf. further below). So too, in the famous opening of Pindar's First Pythian Ode, Typhos' fiery eruptions from below Mount Etna are opposed to Apollo's divine lyre-music and a permanent reminder of the disordered chaos to which the Apolline and Olympian order has put a harmonious end. Zeus and Apollo are responsible for that stability in language, but it is etymology which discloses it to us. Moreover, etymology can also reveal the history leading to that settled order; as such, etymology is very closely linked with aetiology. The story of Apollo's killing of the serpent is, as it were, sealed by a significant 'naming' (subsequently to be revealed by etymology), whether that be of $\Pi \nu \theta \omega$ ' from

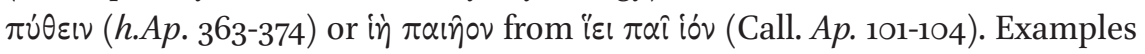
could be multiplied, and there would be much to say about how this pattern intersects with the links between, for example, etymology and allegorising and etymology and the rationalisation of myth. What matters in the present context is that etymology and aetiology are both related manifestations of a way of thinking about cosmic order which was associated by the Greeks with Apollo more than with any other god. Apollo's island, Delos, also points to this truth. In the telling of the story of the island in Pindar and Callimachus, Asterie was 
a floating, movable island until Leto gave birth to Apollo there and the island became fixed and $\Delta \hat{\eta} \lambda$ os, 'clear' (Call. Del. $35-40$ ), as it has remained, and remained as an example to us, ever since.

Immediately after the nest of Apolline etymologies in the Cratylus (covering the god himself, the Muses, Leto and Artemis), Hermogenes questions Socrates about Dionysus and Aphrodite:

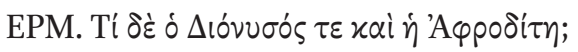

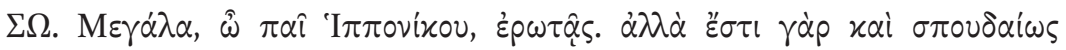

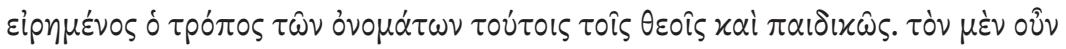

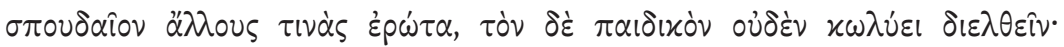

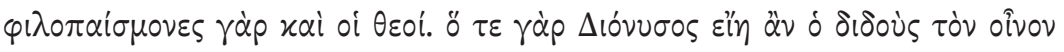

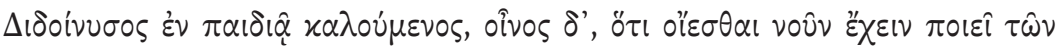

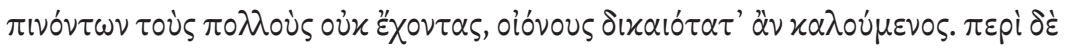

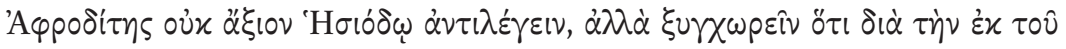

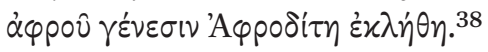

Herm. What of Dionysus and Aphrodite? Soc. O son of Hipponicus, you are asking about weighty matters. The names of these gods may be explained in both a serious and a playful manner. As for the serious one, you will have to ask others, but nothing prevents me giving you the playful account, as gods too like to play games. Dionysus, who gives wine (didous ton onion) might be called Didoinysos in jest, and wine (oinos), because it makes most drinkers think that they have good sense (oiesthai noun), when they do not, might very justly be called 'oionous'. As for Aphrodite, we should not contradict Hesiod, but should agree that she was called Aphrodite because of her birth from the foam (aphros).

Socrates' apparent reticence about Dionysus is usually explained (if indeed it attracts much notice at all) with reference to the Mysteries: the 'serious' etymology for which Hermogenes will have to 'ask others' must have mystical significance. ${ }^{39}$ In the present context, however, other questions arise. Does

38 Pl. Cra. $406 b_{7}-\mathrm{d} 2$.

39 It is unclear whether the belief that Dionysus (and his name) was a latecomer to Greece (cf. Hdt. 2.49.1, 2.52.2, 2.145.1) has also contributed to Socrates' reticence; Herodotus reports that Melampous introduced both Dionysus' name and his rites to the Greeks, and this might put him in a rather different category, i.e. outside the activities of the ancient 'name-givers'. In the late fifth century, Stesimbrotus somewhere etymologised Dionysus'

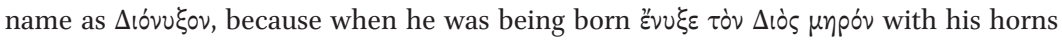
(FGrHist ${ }_{107} \mathrm{~F}_{13}$ ); it is a pity that we do not know the context. 
Plato actually reject the possibility of giving a 'serious' etymology of these gods? The case of Aphrodite is notably ambiguous: are we to understand that the Hesiodic etymology (cf. Hes. Th. 195-198) is the 'playful' one, or does the 'playful' 'serious' distinction really apply only to Dionysus? ${ }^{40}$ More broadly, we may want to ask how this distinction between 'serious' and 'playful' etymologies should affect our understanding of all the other etymologies which Socrates offers.$^{41}$ Does the fact that Dionysus seems to be, from an early date, associated with flux and change make him a difficult subject for etymologising? Is Dionysus in fact the exception which proves the rule or, rather, proves the value of the etymological enterprise? Plutarch's The E at Delphi will address these questions almost directly.

The E at Delphi is the report of a discussion of the meaning of the inscription of an E in the god's principal sanctuary. ${ }^{42}$ The seven postulated explanations cover (inter alia) cultural and philosophical history, linguistics and mathematics. It is clear both that Ammonios' final Platonising disquisition has specially privileged status within the dialogue (cf. perhaps Diotima's speech in Plato's Symposium $)^{43}$ and that all of the explanations are in some

40 Diog. Apoll. A 24 D-K refers the ג̣̇pós in the god's name to male sperm, and this was to become a familiar etymology, cf., e.g., Corn. 24.3 (p. 45 Lang), EM 179.10-11. Any full discussion of this passage of the Cratylus might start from the fact that Dionysus and Aphrodite are frequently found together in Greek poetry and art (cf., e.g. Dodds ${ }^{2} 1960$ on E. Ba. 402-416) and that both gods themselves have a 'doubleness' which may, so Socrates

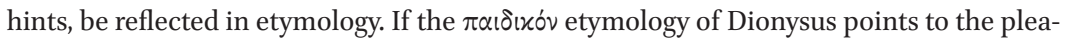
sures of the symposium, rather than to the god's Mysteries and the terrors of Dionysiac cult, Aphrodite embodies both the erotic pleasures (and sufferings) of human beings and also something far grander and more cosmic; one thinks not just of the two Aphrodites of Pausanias' speech in the Symposium, but also of Aphrodite's role in Empedocles' cosmogony.

41 Cf. Trivigno 2012, 49, though we cannot follow the inference which he draws.

42 On this essay cf. esp. Moreschini 1997; Boulogne, Broze and Couloubaritsis 2006; Obsieger 2013; Thum 2013 (with very rich bibliography); Simonetti 2017, 119-177; there is a brief and accessible guide to the essay and its bibliography in Kindt 2016, 169-183, who is particularly concerned with how the attempts to find 'the real meaning' of the E are related to oracular discourse.

43 Cf., e.g., Babut 1992, 190, 194-202; Thum 2013, 4-6, 12-13; Simonetti 2017, 123, 162-166; this important structuring principle finds excellent analogies elsewhere in Plutarch, but by itself is insufficient for a full account of the treatise. On the relation between the views placed in Ammonios' mouth and those of Plutarch himself cf. also Whittaker 1969; Moreschini 1997, 12-33. 
sense in competition: the participants in the recalled discussion are searching for the 'real meaning' of the E, on the assumption that there is indeed a 'real meaning'. It is, however, also clear that the explanations sit comfortably alongside each other; one explanation may be more sophisticated than another, and some more easily dismissed (cf. 386a-b) and/or driven by personal motives (cf. 387f), but all respond, as the introduction to the essay makes clear (384f-385d), to the Apolline impulse to the search for knowledge and philosophical understanding. What matters for Plutarch in the end is not which explanation is 'true' in an absolute, historical sense, but rather the light they all, in different ways and through different intellectual approaches, shed upon the nature of the god in whose sanctuary the inscription stands and upon the history of that sanctuary. ${ }^{44}$ As Elsa Giovanna Simonetti puts it, "all the visions proposed by the characters ... must be considered together, since they all concur to create a complex, multifaceted and dynamic image of the god Apollo".45

What is more, this accretive force at work in The Eat Delphi is not only found elsewhere in Plutarch's philosophising essays, but, we suggest, also finds a clear analogy in ancient etymological practice, above all, of course, in the Cratylus which repeatedly offers multiple etymologies for one and the same name.

Etymology itself plays indeed a significant part in Plutarch's discussion of the meaning of the inscription and hence of the god himself. Plutarch explicitly cites the Cratylus once in The Eat Delphi (391a-b, referring to Cra.409a7-b8), ${ }^{46}$ but the importance of etymologising to, and the accretive force of, different 'rival' accounts of the god suggests that the influence of the Cratylus on Plutarch's essay is not limited to this one passing allusion. Some reactions to the suggested explanations of the E may in fact remind us of some modern views of the etymologies of the Cratylus and of ancient etymologising in general: "Plutarch offers seven different explanations, all of which are fanciful and unsatisfactory, if not impossible". ${ }^{47}$ More importantly, the tension between competing claims to offer the 'true meaning' and expositions in support of those which offer access to cultural and philosophical 'truths', regardless of

44 Cf. the remarks of Broze and Van Liefferinge in Boulogne, Broze and Couloubaritsis 20o6, 8o-81; they do not, however, consider the likeness to etymological practice.

45 Simonetti 2017, 129 (emphasis in the original).

46 At The E at Delphi 393c we are told by Ammonios, in the context of the standard explanation of $\Phi \circ i \beta$ i

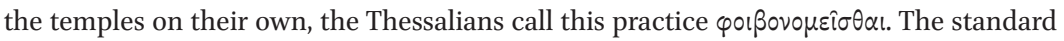
modern commentary (unsurprisingly) notes there is no other evidence for this word or practice, but it is perhaps more than a coincidence that Thessalians are involved, as they also were in the etymologies of Apollo in the Cratylus (405c).

47 Bates 1925, 240. For modern attempts to decode the E cf., e.g., Bates 1925; Berman and Losada 1975; Losada and Morgan 1984; Obsieger 2013, 9-16. 
the historical validity of the exposition as an explanation for the E, can hardly fail to suggest the procedures of the Cratylus. It is that analogy to which we wish to draw attention.

Our principal interest is one of the best known passages of this work, for it is one of the few ancient texts which juxtapose Apollo and Dionysus in a way which seems to look ahead to the dichotomy which Nietzsche, above all, bequeathed to the modern world: ${ }^{48}$

Now we hear the theologians affirming and reciting, sometimes in verse and sometimes in prose, that the god is deathless and eternal ( $\ddot{\alpha} \varphi \theta \alpha p \tau o \varsigma$... xai àióıs) in his nature, but owing to some predestined design and reason, he undergoes transformations of his person, and at one time enkindles his nature into fire and makes it altogether like all else, and at another time he undergoes all sorts of changes in his form, his emotions and his powers, even as the universe does to-day; but he is called by the best known of his names. The more enlightened, however, concealing from the

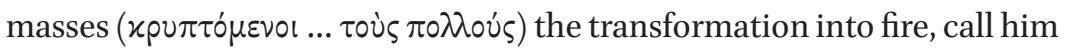
Apollo because of his solitary state ( $\tau \hat{\eta} \mu \circ v \omega \dot{\omega} \sigma \varepsilon)$, and Phoebus because of his purity and stainlessness ( $\tau \hat{\omega} \kappa \alpha \theta \alpha \rho \hat{\omega}$ xai $\alpha \mu(\alpha) \tau \tau)$. And as for his turning into winds and water, earth and stars, and into the generations of plants and animals, and his adoption of such guises, they speak in a riddling way of what he undergoes in his transformation as a tearing apart,

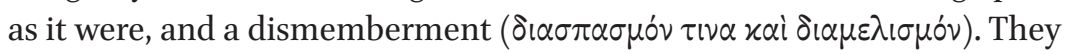
give him the names of Dionysus, Zagreus, Nyctelius, and Isodaetes; they construct destructions and disappearances, followed by returns to life and regenerations - riddles and fabulous tales ( $\alpha i v i \gamma \mu \alpha \tau \alpha$ xai $\mu \nu \theta \varepsilon \dot{\mu} \mu \alpha \tau \alpha)$ quite in keeping with the aforesaid transformations. To this god they also sing the dithyrambic strains laden with emotion and with a transformation that includes a certain wandering and dispersion. Aeschylus, in fact, says (fr. 355 Radt)

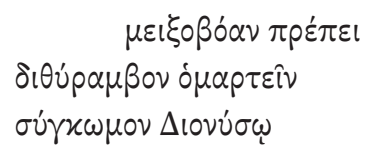

[Fitting it is that the dithyramb with its fitful notes should attend Dionysus in revel rout].

48 On this passage cf. Hunter 2011, 21-23, citing earlier bibliography; Thum 2013, 189-194; Simonetti 2017, 143-146. 
But to Apollo they sing the paean, music regulated and chaste ( $\tau \varepsilon \tau \alpha \gamma \mu \varepsilon \dot{\varepsilon} \eta \nu$ xai $\sigma \dot{\omega} \varphi p \circ v \alpha \mu \circ \hat{\sigma} \sigma \alpha v)$. Apollo the artists represent in paintings and sculp-

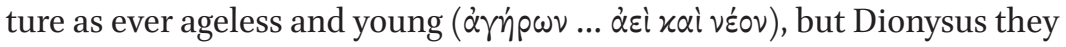
depict in many guises and forms ( $\pi \circ \lambda v \varepsilon\llcorner\delta \hat{\eta}$ xai $\pi \circ \lambda \nu \dot{\mu} \circ \rho \varphi \circ v)$; and they attribute to Apollo in general a uniformity, orderliness, and unadulterated

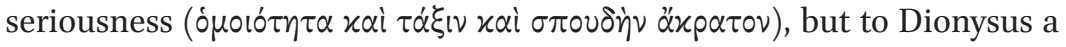
variability combined with playfulness, wantonness, [seriousness], and

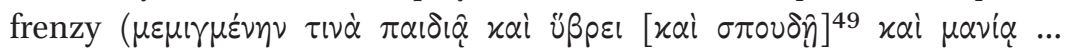
$\alpha v \omega \mu \alpha \lambda i \alpha \nu)$. They call upon him (PMG 1003)

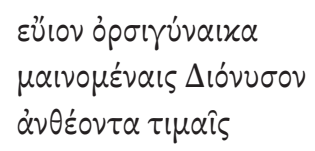

[Euoe Bacchus who incites womankind, Dionysus who delights 'mid his honours fraught with frenzy],

not inappositely apprehending the peculiar character of each transformation. ${ }^{50}$

The passage is replete with explicit and implicit etymologies of Apollo's name. The following is probably a partial list. (i) díôos (388f) looks to the god's connection with $\dot{\alpha} \varepsilon$, which we have already noted from the classical period; this

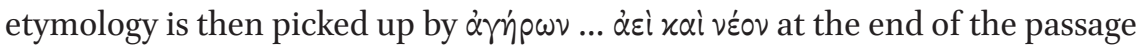

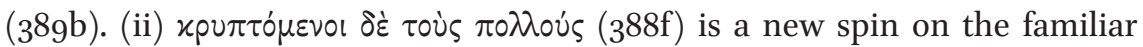
$\dot{\alpha}+\pi \circ \lambda \lambda$-etymology: the true meaning of Apollo is 'not for the many' or 'away from the many, ${ }^{51}$ which stands almost as a programmatic announcement of how some ancient philosophers and religious groupings used the 'mysteries' of etymology (cf. especially the famous allegorical etymologising of the Derveni papyrus). (iii) $\mu o ́ v \omega \sigma \iota \varsigma$ (388f) is standardly taken as another reference to the $\dot{\alpha}+$ $\pi \circ \lambda \lambda$-etymology. The inheritance of $\dot{\alpha} \pi \lambda$ ㅇov from the Cratylus (cf. above $\S 2$ ) is, however, also felt here as elsewhere. In Isis and Osiris we are told (if we accept a very probable emendation) that the Pythagoreans called the number One

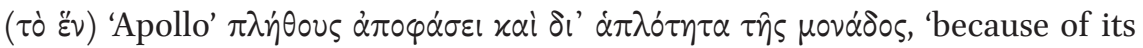

49 del. Wilamowitz.

$5^{\circ} \quad$ Plu. The E at Delphi $388 \mathrm{e}-389 \mathrm{~b}$ (trans. F.C. Babbitt, adapted).

51 In the subsequent contrast between Apollo and Hades at The E at Delphi 394a, Plutarch

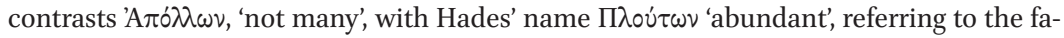
miliar idea that the dead are 'the many' or 'the more', cf., e.g., Ar. Ec. 1073, Call. Epigr. 4 Pf. For the etymology of 'A $\pi \dot{\delta} \lambda \lambda \omega \nu$ as 'not many/much' in the Pythagorean tradition cf. Whittaker 1969, 187 . 
rejection of plurality and the singleness of the monad' (381f), a phrase which gestures both to $\dot{\alpha}+\pi \circ \lambda \lambda$ - and to the etymology from $\dot{\alpha} \pi \lambda \circ \hat{v} v$. The E at Delphi

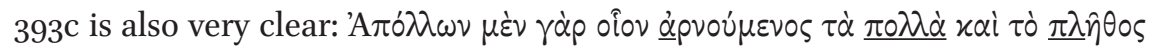

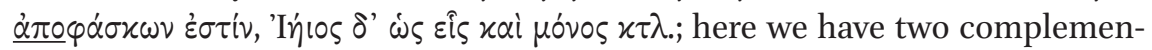
tary etymologies telling the same story. ${ }^{52}$

If Apollo is single, then The E at Delphi $388 \mathrm{e}-389 \mathrm{~b}$ makes very plain that

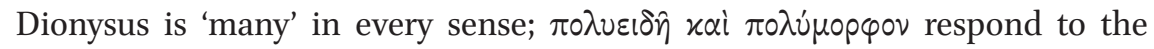
$\dot{\alpha}+\pi \circ \lambda \lambda$-etymology of Apollo to point the difference. With Dionysus, $\dot{\alpha} \nu \omega \mu \alpha \lambda i \alpha$ is the governing principle, both in myth and music. The repeated use of the prefix $\delta 1 \alpha$ - in compounds, which spread from Dionysiac myth $(\delta 1 \alpha \sigma \pi \alpha \sigma \mu o \delta$,

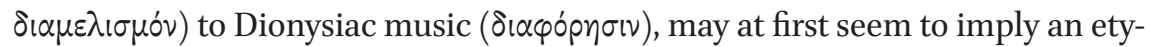
mology of the god's name, and yet the suggestion conveyed by $\delta 1 \alpha$ - of scattering and dissolution seems to be cast in opposition to the directional, almost etymologising, force of $\dot{\alpha} \pi 0$ - at the head of the name of 'A $\pi^{\prime} \dot{\lambda} \lambda \omega \nu .{ }^{53}$ What is clear, moreover, is that in this passage Apollo's unchanging significance is revealed in the etymologies of his two principal names, ${ }^{54}$ whereas the significance of Dionysus is revealed in the very multiplicity of names and forms and the disordered mixture of his music. Even when the multiplicity of Apollo's titles too is recognised (as it is in The E at Delphi), their etymologies insist upon 'oneness' and 'unchangingness' (cf. The E at Delphi 393c). Purity in fact involves unchangingness and lack of mixture, for once change is introduced there is no longer purity; the etymologies of Apollo, Ieios and Phoibos work together in an Apolline harmony. The principal theme of Ammonios' final speech is indeed that Apollo as divine Being is 'eternal and uncreated and indestructible' and not subject to the changes which time brings (392e). This is not the same Apollo as the god of the Cratylus, but the line of intellectual descent is still visible.

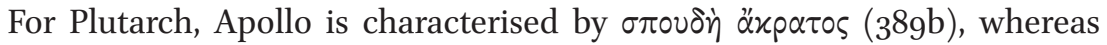
Dionysus is characterised by an outrageous mixture ${ }^{55}$ of which $\pi \alpha 1 \delta \dot{\alpha}^{\prime}$ certainly and $\sigma \pi \circ 0 \delta \eta$ presumably (even with Wilamowitz's deletion) ${ }^{56}$ are parts. Socrates' claim in the Cratylus that there is a serious and a playful etymology of Dionysus' name is precisely appropriate for Dionysus himself:57 Socrates'

52 Cf., e.g., Brout in Boulogne, Broze and Couloubaritsis 2006, 133. The etymology from $\dot{\alpha} \pi \lambda \circ 0 \hat{\nu}$ and Apollo's 'singleness' are central to Proclus' discussion of the god in his Commentary to Plato's Cratylus (pp. 96.12-102.9 Pasquali = Duvick 2007, 96-100).

53 We owe this suggestion to Cédric Scheidegger Laemmle.

54 Apollo has of course elsewhere very many names or titles, particularly in the context of his identification with the sun, all of which carry their own (sometimes multiple) etymological significance; Corn. 31 (pp. 65-70 Lang) and Macr. Sat. 1.17 are the two principal surviving discussions.

55 The language of wine-mixing is of course evoked here.

56 Cf. above n. 49 .

57 Cf. above $\S 2$. 
distinction of two kinds of etymologies for the god tells us something very important about that god. Perhaps it is wine which-Socrates suggests-is the 'playful' manifestation of the god, whereas it is the mystic tearing apart, re-enacted in the ecstatic rites and $\omega \mu \circ \varphi \alpha \gamma i \alpha$ of Dionysiac cult and art, which represent the god in his 'serious' form; we might recall here the contrasts and similarities between Euripides' Cyclops and Bacchae, which both reveal the nature of the god, but in two very different modes. Moreover, in both Plato and Plutarch Dionysus remains resistant to etymologising, ${ }^{58}$ and in Plutarch that is closely linked to his variety and instability: etymology can here reveal no truths about this god, because the only truth is changingness. It is, however, stable verities which etymology reveals.

As we have already noted, the influence of the Cratylus in both antiquity and modern scholarship has established something like an equation between etymology and 'explicit etymology', not merely through Socrates' demonstrations of etymology at work but also through the suggestion that the practice required specialist knowledge or gifts, like $\mu \alpha \nu \tau i x \dot{\eta}$. As one of the consequences of this influence, it is also the Cratylus, or rather the way in which the Cratylus has been read, which has marked off etymologising in poetry, which is much more often 'implicit' than 'explicit', as an 'other' practice. From a historical point of view, this rightly recognises the background of the dialogue in explicit linguistic speculation; 'explicit' etymologising marks a particular, and particularly important, moment in the history of such speculation. Nevertheless, the distinction between the two modes is highly permeable, and the Cratylus, which is full of etymologies which are not explicitly pointed, is itself one of the prime witnesses of this. Part of the discussion of Pan which we have already considered is an excellent illustration:

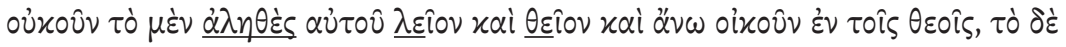

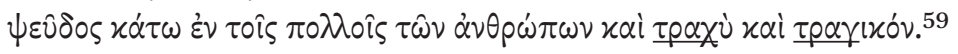

So, the true part of it is smooth and divine and lives up there with the gods. The false part lives down among the mass of men and is rough and tragikon.

\footnotetext{
$5^{8}$ This of course is not to say that the in other contexts the god's name could not be etymologised, cf., e.g., Macr. Sat. 1.18.12-13. 
There is here a rather obvious play between $\tau \dot{0} \alpha \lambda \lambda \eta \theta \dot{\varepsilon} \varsigma$ and $\lambda \varepsilon \hat{\varepsilon} 0 \nu$ xai $\theta \varepsilon \hat{\imath} 0 \nu$, but David Sedley calls this not an etymology but a "quasi-etymological hint", "because it does not constitute an actual etymology of $\dot{\alpha} \lambda \eta \theta \dot{\varepsilon}$ s to compete with the decoding of $\dot{\alpha} \lambda \dot{\eta} \theta \varepsilon$ เ $\alpha$ that will be offered later in the text (421b). Rather, it interprets two visual aspects of Pan as indirectly symbolising $\alpha \lambda \lambda \eta \theta \dot{\varepsilon} \varsigma$ via its discrete vocal components".60 This example and Sedley's discussion show what is at stake in trying to make too firm a distinction between 'explicit' etymology and poetic and/or 'implicit' etymological play. What name would one give to the assonance of $\tau \rho \alpha \chi \dot{v}$ and $\tau p \alpha \gamma$ ixóv and the rhyme of $\lambda \varepsilon \hat{0} 0 v$ and $\theta \varepsilon i \hat{o v}$ ? Poetic stylisation or poetic etymologising, or both? The richly various forms of etymologising bleed into each other, as we have seen dramatised in Cassandra's anguish in the Agamemnon. Despite the familiarity of 'explicit' etymologising from Homer onwards and despite the almost inexhaustible variety of etymologising on display in the dialogue itself, it was the influence of the Cratylus which created a hierarchy of the 'explicit' and the 'implicit'.

One distinction which might be drawn between the two modes is that there will always be a residue (perhaps even a majority) of suggested cases of 'implicit' etymology where there will be room for disagreement as to the deliberateness of the effect. That etymological play has a significant role in Greek poetry of every period requires no elaborate demonstration, but it is equally uncontroversial that alleged cases are always matters for critical judgement, a fact which itself points to the peculiar purposes of ancient etymologising. What both the Cratylus and The E at Delphi illustrate is the cultural significance of these intellectual practices, regardless of one's view of how 'seriously' to take the Platonic dialogue, or indeed the Plutarchan explanations offered for the E at Delphi. Etymologising lays bare not merely structures of thought which pervade the world, but also the theological framework which keeps those structures in place.

To draw our discussion to a close, we want to go all the way back to Apollo's very entry into Greek literature:

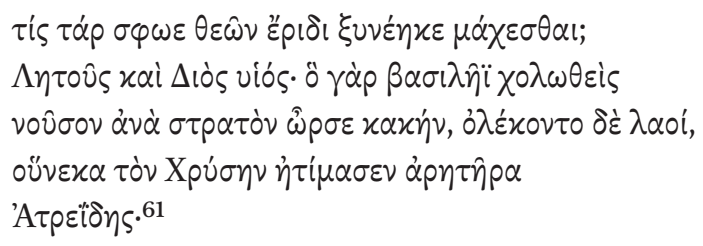

6o Sedley 2003, 96 .

61 Hom. Il. 1.8-12. The textual difficulty in v. 11 does not affect the point we wish to make. 
Which of the gods brought the two of them together in strife? The son of Leto and Zeus. For in anger against the king he caused evil sickness through the army, and the soldiers perished, because the son of Atreus dishonoured the priest Chryses.

'The son of Leto and Zeus' may be a suitably epic circumlocution, but does it also avoid a name, the dangers of which are then revealed — or rather hinted

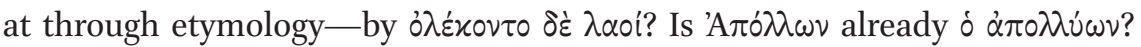
Etymologising, like allegorising, can be dark and threatening, and Apollo's dread appearance in Iliad 1 was certainly much allegorised. Moreover, although medicine is, famously, the one of his four (later) arts which the baby god does not claim in his very first spoken words at $h . A p .131-132$, here at the opening of the Iliad he is already associated with disease (the healing god is also the bringer of plague, cf. Corn. 32.4 p. 65-66 Lang etc.) and destruction; in different ways, Iliad 1 certainly puts on display Apollo's three other arts-archery, prophecy and (at the end of the book, vv. 603-604) music.

If Apollo's first entry raises etymological queries, what of his action in response to Chryses' prayer?

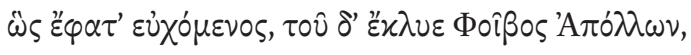

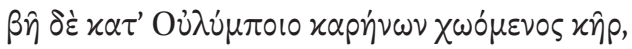

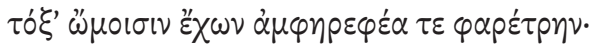

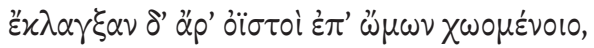

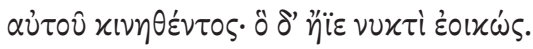

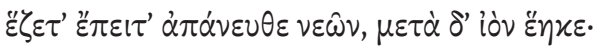

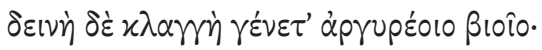

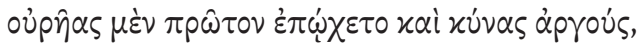

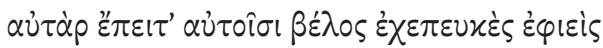

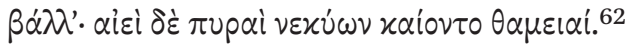

So Chryses spoke in prayer, and Phoebus Apollo heard him. Angry in his heart, he came down from the peaks of Olympus, with his bow and his hooded quiver slung around his shoulders. The arrows clanged on his shoulders as the angry god moved. He came like night. He then sat down away from the ships and launched an arrow; there was a terrible clanging from his silver bow. He aimed first at the mules and the swift dogs, and then he launched his piercing bolt at the men; pyres of the dead burned incessantly. 
$\beta \alpha \dot{\lambda} \lambda(\varepsilon)$ and $\alpha \dot{l} \varepsilon \dot{l}$ are separated by punctuation (as $\delta \dot{\varepsilon}$ shows), but can we be sure that the etymology for the archer-god's name which was to become so familiar from Plato and later texts ( $\dot{\alpha} \varepsilon i \beta \dot{\alpha} \lambda \lambda \omega \nu)$ does not already resonate here, or would be felt by Homeric audiences from a relatively early date? ${ }^{63}$ More generally, these examples in the Iliad are excellent illustrations not just of the 'room for disagreement' to which we have already referred, but also of the (obvious) fact that 'implicit etymologising' demands the co-operation of the audience and that the nature of that co-operation is likely to change over time. Someone who knows the Cratylus' discussion of Apollo's name is bound to read Iliad 1.52 or 17.118 differently from someone who does not; (s)he will then have to decide how and if to use this knowledge in understanding Homer, but there will always be a choice to be made. Not entirely unlike etymologists, in fact, audiences of all kinds look for meaningful signs in texts and in collections (and collocations) of letters, and Apollo rarely disappoints.

\title{
Appendix: A Shot in the Dark
}

Apollo's response to Chryses' prayer at the start of the Iliad has no real parallel in other divine interventions in Homer, but certain elements of it appear again in Odysseus' famous, and famously problematic, ${ }^{64}$ description of the $\varepsilon^{\prime 1} \delta \omega \lambda$ ov of Heracles in the Underworld: 65

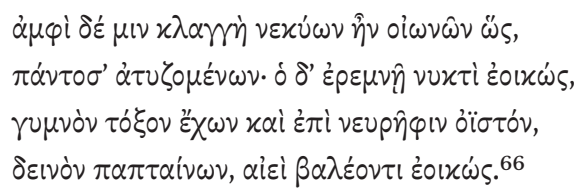

\begin{abstract}
About him the dead clamoured like birds as they scatted in all directions in panic, but he was like gloomy night, holding his bow at the ready with an arrow on the string, glaring around fiercely, looking like one who would shoot at any moment.
\end{abstract}

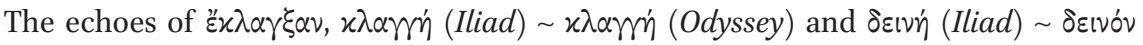

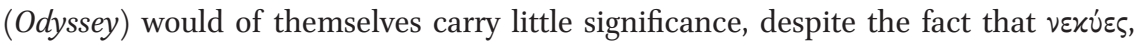

63 See further the Appendix.

64 For ancient discussion of some of the problems cf. Petzl 1969, 28-41.

65 Some of the parallels noted here are helpfully discussed by Karanika 2011, 12-13.

66 Hom. Od. 11.6o5-6o8. 


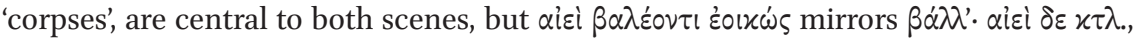
and the two passages also share the only two occurrences in Homer of the verse-end

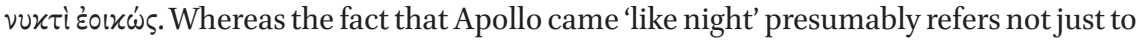
the speed with which he moved, but also suggests a frightening and mysterious power, ${ }^{67}$ Heracles is most 'like gloomy night' in that the Underworld in which he stalks is itself of

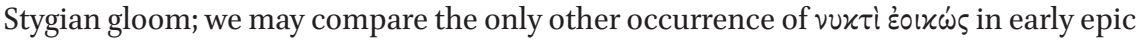
outside Homer:

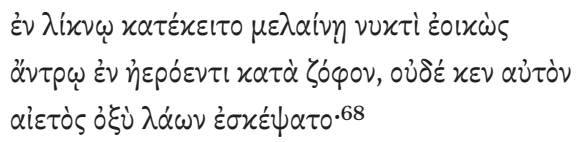

He lay down in his cradle, like black night in the darkness of the gloomy cave; not even a sharp-sighted eagle would have seen him.

The baby god is essentially invisible in his gloomy cave; in blending into the darkness he is 'like black night', but there is nothing frightening about him, despite the mischief he is plotting. ${ }^{69}$ The speaker of these verses is Apollo himself, Hermes' principal antagonist in the Hymn, and he uses a phrase which Homer had used of Apollo in the Iliad. ${ }^{70}$ The poet of the Hymn thus almost provides a commentary on the Homeric

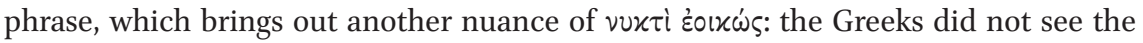
god who attacked them, for 'he sat far off from the ships' (Il. 1.48). Apollo's invisibility to the Greeks is then transferred to the baby hiding in his cradle in the depths of a gloomy cave.

The poet of the Odyssey-passage, however, presumably wished to suggest both the darkness surrounding the ghostly Heracles and the terror he inspired in the shades around him. The eidolon of Heracles cannot have been quite invisible, for Odysseus

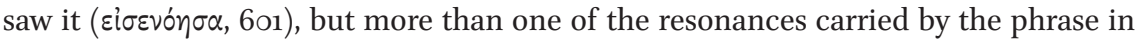
Iliad 1 were taken over by the poet of the Odyssey-verses, in a passage whose import and syntax have puzzled readers since antiquity. The frightening Olympian archer and the frightening archer of the Underworld seem too alike to invoke coincidence or the fact that, in early epic, similar material will inevitably be described in similar

67 Cf. Hunter 2018, 43-44.

68 h.Merc. 358-36o.

69 Thomas (forthcoming) on vv. 358-359 and 334-364 of the Homeric Hymn to Hermes argues that Apollo indeed wishes to cast Hermes as a threat; on the association of Hermes and night in the Hymn see also Thomas, Introduction $\$ 4.3$.

70 That the Hymn here echoes Iliad 1 has, of course been suggested in the past, though scholars have differed as to the tone and purpose of the echo, cf. the notes of Gemoll 1886 ("unzweifelhafte Parodie"); Richardson 2010 and Vergados 2013 ad loc. 
or identical language. Rather, the conspicuous doubling within three verses of similes describing the eidolon of Heracles, both expressed with żoxw's at verse-end, suggests that the poet of these Odyssey verses had the opening of Iliad 1 in mind in composing the account of Heracles in the Underworld.

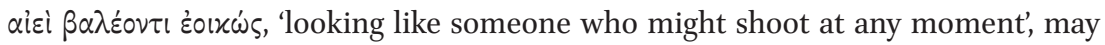

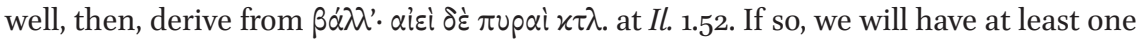
ancient testimony that $\beta \alpha^{\prime} \lambda \lambda^{\prime} \cdot \alpha i \varepsilon i^{\prime}$ in the Iliad might be felt to hang together, despite the punctuation which keeps them apart. But perhaps more crucially, the Odyssey may compare Heracles not to just anyone 'about to shoot at any moment' but to the one god

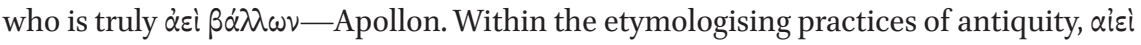

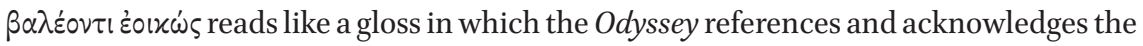
Iliadic pre-text. ${ }^{71}$

\section{Bibliography}

Babut, D. (1992). La composition des Dialogues pythiques de Plutarque et le problème de leur unité. Journal des Savants 2, pp. 187-234.

Bates, W.N. (1925). The E of the Temple at Delphi. AJA 29, pp. 239-246.

Berman, K., and Losada, L.A. (1975). The Mysterious E at Delphi. A Solution. ZPE 17, pp. 115-117.

Boardman, J. (1997). Pan. LIMC VIII Suppl. I, pp. 923-941; II, pp. 612-635.

Boardman, J. (2009). Pan. LIMC Supplementum I, p. 409; II, p. 197.

Boulogne, J., Broze, M., and Couloubaritsis, L., eds. (2006). Les Platonismes des premiers siècles de notre ère. Plutarque, L'E de Delphes. Brussels.

Brommer, F. (1956). Pan. RE Suppl. 8, pp. 949-10o8.

Burkert, W. (1962). Weisheit und Wissenschaft. Nürnberg.

Burkert, W. (1975). Apellai und Apollon. RhM 118, pp. 1-21 [= Kleine Schriften, Vol. 6, Göttingen 2011, pp. 3-20].

Diggle, J. (1970). Euripides, Phaethon. Cambridge.

Dillery, J. (2005). Chresmologues and Manteis. Independent Diviners and the Problem of Authority. In: S.I. Johnston and P.T. Struck, eds., Mantikê. Studies in Ancient Divination, Leiden, pp. 167-231.

71 We are very grateful to Cédric Scheidegger Laemmle, Constanze Guethenke and the participants of ETYGR 2018, 2nd International Conference on Etymological Theories and Practice in Greek (Nice, France) for much helpful discussion and criticism; we have also benefitted from the suggestions of the journal's two anonymous referees. Oliver Thomas very kindly gave us access to his forthcoming commentary on the Homeric Hymn to Hermes. 
Dodds, E.R. (1960). Euripides, Bacchae. Edited with Introduction and Commentary. 2nd edition. Oxford [1st ed: 1944].

Duvick, B. (2007). Proclus, On Plato's Cratylus. Ithaca, NY.

Flacelière, R. (1974). Plutarque, OEuvres morales, Vol. 6: Dialogues pythiques. Paris.

Flinterman, J.-J. (2014). Pythagoreans in Rome and Asia Minor around the Turn of the Common Era. In: C.A. Huffman, ed., A History of Pythagoreanism, Cambridge, pp. 341-359.

Flower, M. (2008). The Seer in Ancient Greece. Berkeley, CA.

Gemoll, A. (1886). Die homerischen Hymnen. Leipzig.

Goslin, O. (2010). Hesiod's Typhonomachy and the Ordering of Sound. TAPhA 140, pp. 351-373.

Heubeck, A. (1987). Noch einmal zum Namen des Apollon. Glotta 65, pp. 179-182.

Hordern, J.H. (2002). The Fragments of Timotheus of Miletus. Oxford.

Hunter, R. (1986). Apollo and the Argonauts. $M H 43$, pp. 50-6o [= Hunter 20o8, pp. 29-41].

Hunter, R. (2008). On Coming After. Studies in Post-Classical Greek Literature and its Reception. Berlin/New York.

Hunter, R. (2011). Apollo and the Ion of Euripides. Nothing to Do with Nietzsche? Trends in Classics 3, pp. 18-37.

Hunter, R. (2018). The Measure of Homer. Cambridge.

Karanika, A. (2011). The End of the Nekyia. Odysseus, Heracles, and the Gorgon in the Underworld. Arethusa 44, pp. 1-27.

Kindt,J. (2016). Revisiting Delphi. Religion and Storytelling in Ancient Greece. Cambridge.

Kretschmer, P. (1927). Literaturbericht für das Jahr 1924. Glotta 15, pp. 161-201.

Losada, L.A., and Morgan, K. (1984). The E at Delphi Again. Reply to A.T. Hodge. AJA 88, pp. 231-232.

Moreschini, C. (1997). L'E di Delfi. Naples.

Morgan, K. (2010). The Voice of Authority. Divination and Plato's Phaedo. CQ 6o, pp. $63-81$.

Most, G.W. (2016). Allegoresis and Etymology. In: A. Grafton and G.W. Most, eds., Canonical Texts and Scholarly Practices, Cambridge, pp. 52-74.

Nagy, G. (2004). The Name of Apollo. Etymology and Essence. In: Id., Homer's Text and Language, Urbana/Chicago, 138-143.

Nightingale, A.W. (2003). Subtext and Subterfuge in Plato's Cratylus. In: A.N. Michelini, ed., Plato as Author. The Rhetoric of Philosophy, Leiden, pp. 223-240.

Obsieger, H. (2013). Plutarch. De E apud Delphos. Über das Epsilon am Apolltempel in Delphi. Stuttgart.

Petzl, G. (1969) Antike Diskussionen über die beiden Nekyiai. Meisenheim am Glan.

Pfeiffer, R. (1949) Callimachus, Vol. ı. Oxford.

Rank, L.P. (1951). Etymologiseering en verwante verschijnselen bij Homerus. Assen. 
Richardson, N. (2010). Three Homeric Hymns. To Apollo, Hermes, and Aphrodite. Cambridge.

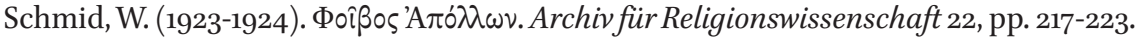
Sedley, D. (2003). Plato's Cratylus. Cambridge.

Segal, C. (1982). Etymologies and Double Meanings in Euripides' Bacchae. Glotta 6o, pp. 81-93.

Simonetti, E.G.(2017). A Perfect Medium? Oracular Divination in the Thought of Plutarch. Leuven.

Sluiter, I. (2015). Ancient Etymology. A Tool for Thinking. In: F. Montanari, S. Matthaios, and A. Rengakos, eds., Brill's Companion to Ancient Greek Scholarship, Vol. 2, Leiden/Boston, pp. 896-922.

Struck, P.T. (2016). Divination and Human Nature. Princeton, NJ.

Thomas, O. (2011). The Homeric Hymn to Pan. In: A. Faulkner, ed., The Homeric Hymns. Interpretative Essays, Oxford, pp. 151-172.

Thomas, O. (forthcoming). The Homeric Hymn to Hermes. Cambridge.

Thum, T. (2013). Plutarchs Dialog De E apud Delphos. Tübingen.

Too, Y.L. (2004). The Idea of Ancient Literary Criticism. Oxford.

Trivigno, F.V. (2012). Etymology and the Power of Names in Plato's Cratylus. AncPhil 32, pp. $35^{-75}$.

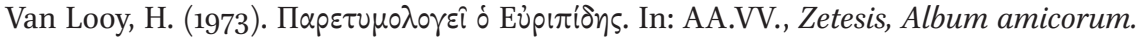
Festschrift E. de Strycker, Antwerp/Utrecht, pp. 345-366.

Vergados, A. (2013) The Homeric Hymn to Hermes. Introduction, Text and Commentary. Berlin.

Whittaker, J. (1969). Ammonius on the Delphic E. CQ 19, pp. 185-192. 